\title{
The effect of bleaching agents on the degradation of vitamins and carotenoids in spray-dried whey protein concentrate
}

\author{
M. A. Stout, C. W. Park, and M. A. Drake ${ }^{1}$ \\ Department of Food, Bioprocessing and Nutrition Science, Southeast Dairy Foods Research Center, North Carolina State University, \\ Raleigh 27695
}

\begin{abstract}
Previous research has shown that bleaching affects flavor and functionality of whey proteins. The role of different bleaching agents on vitamin and carotenoid degradation is unknown. The objective of this study was to determine the effects of bleaching whey with traditional annatto (norbixin) by hydrogen peroxide (HP), benzoyl peroxide (BP), or native lactoperoxidase (LP) on vitamin and carotenoid degradation in spraydried whey protein concentrate $80 \%$ protein (WPC80). An alternative colorant was also evaluated. Cheddar whey colored with annatto $(15 \mathrm{~mL} / 454 \mathrm{~L}$ of milk) was manufactured, pasteurized, and fat separated and then assigned to bleaching treatments of $250 \mathrm{mg} / \mathrm{kg} \mathrm{HP}$, $50 \mathrm{mg} / \mathrm{kg} \mathrm{BP}$, or $20 \mathrm{mg} / \mathrm{kg} \mathrm{HP}$ (LP system) at $50^{\circ} \mathrm{C}$ for $1 \mathrm{~h}$. In addition to a control (whey with norbixin, whey from cheese milk with an alternative colorant (AltC) was evaluated. The control and AltC wheys were also heated to $50^{\circ} \mathrm{C}$ for $1 \mathrm{~h}$. Wheys were concentrated to $80 \%$ protein by ultrafiltration and spray dried. The experiment was replicated in triplicate. Samples were taken after initial milk pasteurization, initial whey formation, after fat separation, after whey pasteurization, after bleaching, and after spray drying for vitamin and carotenoid analyses. Concentrations of retinol, a-tocopherol, water-soluble vitamins, norbixin, and other carotenoids were determined by HPLC, and volatile compounds were measured by gas chromatography-mass spectrometry. Sensory attributes of the rehydrated WPC80 were documented by a trained panel. After chemical or enzymatic bleaching, WPC80 displayed 7.0 to $33.3 \%$ reductions in retinol, $\beta$-carotene, ascorbic acid, thiamin, $\alpha$-carotene, and $\alpha$-tocopherol. The WPC80 bleached with BP contained significantly less of these compounds than the HP- or LP-bleached WPC80. Riboflavin, pantothenic acid, pyridoxine, nicotinic acid, and cobalamin concentrations in fluid whey
\end{abstract}

Received March 24, 2017.

Accepted June 2, 2017.

${ }^{1}$ Corresponding author: maryanne_drake@ncsu.edu were not affected by bleaching. Fat-soluble vitamins were reduced in all wheys by more than $90 \%$ following curd formation and fat separation. With the exception of cobalamin and ascorbic acid, water-soluble vitamins were reduced by less than $20 \%$ throughout processing. Norbixin destruction, volatile compound, and sensory results were consistent with previous studies on bleached WPC80. The WPC80 colored with AltC had a similar sensory profile, volatile compound profile, and vitamin concentration as the control WPC80.

Key words: vitamin, degradation, bleaching, whey

\section{INTRODUCTION}

The production of whey protein concentrate (WPC; 25 to $89.9 \%$ protein) has grown considerably in recent years. In 2014, approximately 244 million kilograms of WPC were produced in the United States (USDA, 2015), representing a $29.6 \%$ increase in WPC sales from 2009 (USDA, 2010). As an ingredient, WPC is often utilized for its unique functional properties (Foegeding et al., 2002; Davis and Foegeding, 2007; Gbassi et al., 2009) and for its high-quality AA profile (Coker et al., 2012; Yang et al., 2012; Candow et al., 2006). These characteristics have made WPC a useful ingredient as a protein additive (Varnam and Sutherland, 1994; Graf et al., 2011), an emulsifier (Foegeding et al., 2002), and a thickening agent (Foegeding et al., 2006). However, WPC produced from colored Cheddar cheese retains approximately $10 \%$ of the added annatto colorant, which, unless removed, limits its application as a food ingredient (Jervis et al., 2012; Smith et al., 2014). The primary colorant used for Cheddar cheese is annatto (Scotter, 2009), a naturally occurring plant seed that has a dark orange color and comprises the carotenoid norbixin (Kang et al., 2010). Because norbixin is soluble in polar solutions, approximately $10 \%$ of this compound is not retained in the cheese curd and is present in the whey (Smith et al., 2014).

Oxidizing bleaching agents effectively degrade norbixin by disrupting the double bonds that compose the chromophore of norbixin (Winter et al., 2008; Kang 
et al., 2010). Although effective at removing color, these chemical bleaches are nonspecific and promote lipid oxidation, causing off-flavors in spray-dried whey ingredients (Campbell et al., 2012; Jervis et al., 2012, 2015; Smith et al., 2015). Both chemical (hydrogen peroxide and benzoyl peroxide) and enzymatic (lactoperoxidase) bleaching agents can be applied to remove norbixin with variable results dependent on bleaching agent and bleaching conditions, but all function as oxidizing agents and can contribute lipid oxidation and off-flavors (Campbell et al., 2012, 2014; Jervis et al., 2012; Smith et al., 2015).

One question that has not been addressed is how bleaching agents affect degradation of vitamins. Chemical bleaching reduces vitamin and carotenoid contents in white flour (McCay 1985; Guo et al., 2016). Native peroxidase in vegetables and fruit can degrade ascorbic acid, anthocyanins, fatty acids, and carotenoids (Sivasankar, 2002). However, little work has been done to address how bleaching agents affect vitamins in whey protein ingredients. Although flavor is the primary driver in liking of protein beverages, nutrient composition is an important indicator of consumer acceptance of these products (Childs et al., 2008; Oltman et al., 2015). Riboflavin, pantothenic acid, and cobalamin are above $10 \%$ of the nutritional daily value for a typical serving size of whey protein. Other vitamin content is below labeling ranges for a typical serving size of unfortified whey protein, but people that consume several servings of whey protein a day may get a significant amount of vitamins from whey protein. It is therefore important to understand how to minimize the degradation of key nutrients during whey processing. Due to the flavor and functional effects of bleaching, alternative colorants for Cheddar cheese that do not partition into the whey have been proposed (Kang et al., 2012; Smith et al., 2014). The objective of this study was to determine the effects of bleaching whey containing traditional annatto colorant with hydrogen peroxide (HP), benzoyl peroxide (BP), or native lactoperoxidase $(\mathbf{L P})$ on vitamin and carotenoid degradation in WPC80. A control unbleached colored whey and a whey from cheese colored with an alternate $\beta$-carotene colorant were also included.

\section{MATERIALS AND METHODS}

\section{Experimental Design}

For each experimental replication, whey was manufactured in the North Carolina State University (NCSU) dairy pilot plant from one lot of whole-fat, raw bovine milk from the NCSU dairy enterprise system. Each lot of milk was processed on the same day it was received.
Table 1. Sampling points for whey processing

\begin{tabular}{lc}
\hline Production point & $\begin{array}{c}\text { Stage of } \\
\text { processing }\end{array}$ \\
\hline Milk following pasteurization & 1 \\
Whey drained from vat & 2 \\
Liquid whey following fat separation before HTST & 3 \\
Liquid whey following pasteurization & 4 \\
Liquid whey following bleaching treatment & 5 \\
Retentate stream following ultrafiltration & 6 \\
Spray-dried powder & 7 \\
\hline
\end{tabular}

The milk was divided into 2 portions; one was used to produce Cheddar cheese colored with norbixin, and the other was used to make Cheddar cheese colored with an alternative colorant (AltC) at the recommended dosage of $23 \mathrm{~mL} / 454 \mathrm{~kg}$ of milk (DairyMax Orange Red 002, a $\beta$-carotene-based colorant; Chr. Hansen, Copenhagen, Denmark). The whey from both vats was processed into powdered WPC80. Approximately $120 \mathrm{~mL}$ of sample was collected at each of 7 points throughout processing (Table 1). Liquid samples and powdered WPC80 for vitamin and carotenoid testing were stored at $-80^{\circ} \mathrm{C}$ until evaluation $(<30 \mathrm{~d})$. Descriptive sensory analysis and volatile compound analysis were also performed on powdered WPC80. Manufacturing procedures were repeated in triplicate, from 3 different batches of milk.

\section{WPC Manufacture}

The WPC80 was manufactured as described by Park et al. (2014), with raw whole milk received from the NCSU dairy enterprise system. Approximately $68 \mathrm{~kg}$ of raw whole milk was HTST pasteurized at $73^{\circ} \mathrm{C}$ for $17 \mathrm{~s}$ (model MPD1050, Micro Process Design, D\&F Equipment Co., McLeansville, NC). Milk was separated into 2 cheese vats, heated to $31^{\circ} \mathrm{C}$, and inoculated with a mesophilic starter culture (Choozit MA 11, Danisco, New Century, NJ) at a concentration of 50 direct culture units $/ 454 \mathrm{~kg}$ of milk. Calcium chloride $(50 \% \mathrm{wt} /$ vol, Dairy Connection Inc., Madison, WI) was then added to both vats at $0.39 \mathrm{~mL} / \mathrm{kg}$ of milk. The milk was ripened for 30 min under constant agitation before colorants were added based on treatment. One vat received double-strength annatto (Con; Cheese Color DS Double Strength, Dairy Connection Inc.) at a rate of $15 \mathrm{~mL} / 454 \mathrm{~kg}$ and the other received the alternate colorant (AltC; DairyMax Orange Red 002, Chr. Hansen) at a rate of $23 \mathrm{~mL} / 454 \mathrm{~kg}$, before being allowed to ripen for an additional 30 min. Double-strength recombinant rennet (Dairy Connection Inc.) was then added at a rate of $0.09 \mathrm{~mL} / \mathrm{kg}$ and allowed to set for $30 \mathrm{~min}$. The coagulum was cut into cubes approximately 2.54 $\mathrm{cm}$ in length and allowed to rest for $5 \mathrm{~min}$, followed by gradual heating to $39^{\circ} \mathrm{C}$ over the course of $30 \mathrm{~min}$ 
with gentle agitation. Once a $\mathrm{pH}$ of 6.35 was achieved, the whey was drained through a sieve, separated, and pasteurized at $73^{\circ} \mathrm{C}$ for $17 \mathrm{~s}$ (model MPD1050, Micro Process Design, D\&F Equipment Co.), at which point the sweet whey was ready for individual treatments.

All samples that received a bleaching treatment were drawn from the annatto-colored whey. All treatments were held at $50.0 \pm 0.5^{\circ} \mathrm{C}$ and maintained at that temperature throughout the duration of this step. Bleaching treatments included HP with $250 \mathrm{mg} / \mathrm{kg}$ hydrogen peroxide (Sigma-Aldrich, St. Louis, MO), BP with 50 $\mathrm{mg} / \mathrm{kg}$ benzoyl peroxide (Luperox A40FP-EZ9, Arkema Inc., King of Prussia, PA), and LP with $20 \mathrm{mg} / \mathrm{kg}$ hydrogen peroxide used to activate the native lactoperoxidase (Campbell and Drake, 2013a, 2014), and a control with no added bleaching treatment. The AltC-treated whey did not receive a bleaching treatment but was held at the same temperature for the same time as the other treatments. After $1 \mathrm{~h}$, wheys containing hydrogen peroxide (HP and LP) were treated with catalase (FoodPro CAT; Danisco) at a rate of $20 \mathrm{mg} / \mathrm{kg}$ to consume any remaining HP. Wheys were then filtered through a UF unit (model Pellicon 2, Millipore Inc., Darmstadt, Germany) containing 5 polyethersulfone cartridge membrane filters (model P2B010V05; 10-kDa nominal separation cutoffs, $0.5-\mathrm{m}^{2}$ surface area; Millipore Inc.). Following primary filtration, samples were diluted with deionized water and diafiltered until the protein content of the retentate reached $80 \%$, as determined by a Sprint rapid protein analyzer (CEM Corp., Matthews, NC) and a Smart System 5 moisture/solids analyzer (CEM Corp.). Samples were then spray dried (model Lab 1; Anhydro Inc., Søborg, Denmark) with an inlet temperature of $200^{\circ} \mathrm{C}$ and an outlet temperature of $90^{\circ} \mathrm{C}$. Following the drying step, samples were placed in Mylar bags and stored at $-80^{\circ} \mathrm{C}$.

\section{Proximate Analysis}

Samples for vitamin and carotenoid analysis were drawn at 7 different points throughout processing (Table 1). For each sample, approximately $120 \mathrm{~mL}$ of product was taken. The total solids of each liquid sample were determined by forced draft oven (AOAC International, 2012; method 990.20; 33.2.44). The total fat of each sample was determined by ether extraction using a modified Mojonnier method (AOAC International, 2012; method 932.06; 33.5.08).

Powdered WPC80 samples were measured for total solids, fat content, and total protein. Percent moisture was measured using a vacuum oven (AOAC International, 2012; method 990.20; 33.2.44). The total fat content was measured by ether extraction using a modified
Mojonnier method (AOAC International, 2012; method 932.06; 33.5.08). Total protein was measured using the Kjeldahl method (AOAC International, 2012; method $991.20 ; 33.2 .11$ ) by multiplying total nitrogen by a factor of 6.38 .

\section{Vitamin and Carotenoid Analyses}

All extractions were performed under filtered lighting designed to limit UVA and UVB radiation below 520 nm (Ergomart, Dallas, TX). Powdered WPC80 samples were rehydrated to $5.0 \pm 0.2 \%$ solids with deionized water before testing. Liquid samples were diluted to $5.0 \pm 0.2 \%$ solids with deionized water before measurement. Frozen liquid samples were first thawed at $37^{\circ} \mathrm{C}$ (Giuliano et al., 1992) before being vortexed. All samples were measured in triplicate.

\section{Retinol and Carotenoid Determination}

Retinol, $\beta$-carotene, $\alpha$-carotene, and lutein concentrations were determined by HPLC as outlined by Giuliano et al. (1992) with minor adjustments. Twelve milliliters of liquid or rehydrated sample $(5.0 \%$ solids) was added to a container with $5 \mathrm{~mL}$ of ethyl alcohol (Sigma-Aldrich) and $3 \mathrm{~mL}$ of $50 \%$ (wt/vol) $\mathrm{KOH}$ (VWR, Radnor, PA) dissolved in deionized water. Samples were flushed with nitrogen, capped with a Teflon-lined phenolic cap, and sonicated for $5 \mathrm{~min}$. Samples for retinol and $\beta$-carotene determination were allowed to mix for $16 \mathrm{~h}$ on an oscillating plate mixer (Thermolyne RotoMix Type 50800, Marshall Scientific, Hampton, NH) at 180 rotations/min, whereas samples for $\alpha$-carotene and lutein analysis were saponified for 30 min on an oscillating plate mixer under the same conditions. After the saponification step, $6 \mathrm{~mL}$ of hexane (Sigma-Aldrich) was poured into each vial, vortexed, sonicated for $5 \mathrm{~min}$, and centrifuged at $800 \times g$ for $10 \mathrm{~min}$. The hexane layer was then extracted and the aqueous phase treated with an additional $3 \mathrm{~mL}$ of hexane. This complex was then vortexed, sonicated for $5 \mathrm{~min}$, and centrifuged again. The resulting hexane phase was extracted and added to the original hexane component and evaporated under nitrogen until 1 to 2 $\mathrm{mL}$ of hexane remained.

The hexane phase was then treated with $2.5 \mathrm{~mL}$ of ethanol and $3.5 \mathrm{~mL}$ of HPLC-grade water (Fluka, Seelze, Germany). The complex was vortexed, sonicated for $5 \mathrm{~min}$, and centrifuged for $10 \mathrm{~min}$ at $800 \times \mathrm{g}$. The hexane layer was transferred into another container and the aqueous phase was treated with $3 \mathrm{~mL}$ of hexane before being sonicated and centrifuged as before. Both hexane layers were combined and evaporated to dry- 
ness with nitrogen before being dissolved in $600 \mu \mathrm{L}$ of HPLC-grade tetrahydrofuran (THF)-methanol (20:80 vol/vol) complex (Sigma-Aldrich and Fluka, respectively). Samples were then filtered with $0.20-\mu \mathrm{m}$ nylon (VWR) and $20.0 \mu \mathrm{L}$ was injected onto an HPLC unit with a $\mathrm{C}_{18}$ reversed phase column (Kinelex 5u XB-C18 $100 \times 4.60 \mathrm{~mm}$, Phenomenex, Torrance, CA) with a flow rate of $0.7 \mathrm{~mL} / \mathrm{min}$. Aliquots of each sample were then eluted with a mobile phase composed of $10 \%$ THF, $90 \%$ methanol, and $0.5 \mathrm{~g} / \mathrm{L}$ butylated hydroxytoluene (Sigma-Aldrich, St. Louis, MO). Column temperature was maintained at $28^{\circ} \mathrm{C} \pm 0.6^{\circ} \mathrm{C}$ and flow rate was maintained at $0.25 \mathrm{~mL} / \mathrm{min}$. Peaks were analyzed using a Waters 2998 photodiode array detector (Waters, Milford, MA) set at $448 \mathrm{~nm}$ for $\beta$-carotene, 325 $\mathrm{nm}$ for retinol, and $452 \mathrm{~nm}$ for all other carotenoids. Compound concentrations were determined based on standard curves composed of 6 dilutions of $\geq 99.0 \%$ crystalline retinol (Sigma-Aldrich), $\geq 99.5 \% \beta$-carotene (Sigma-Aldrich), $\geq 99.5 \%$ a-carotene (Sigma-Aldrich), and $\geq 99.5 \%$ lutein (Sigma-Aldrich). Each sample was extracted in triplicate. Each extraction was injected and measured chromatographically twice. Norbixin was extracted from fluid wheys and powders and quantified as described by Campbell et al. (2014).

\section{Ascorbic Acid Determination}

Ascorbic acid concentration was determined using the HPLC method outlined by Romeu-Nadal et al. (2006). Three hundred microliters of fluid or rehydrated whey $(5.0 \pm 0.2 \%$ solids $)$ was mixed with $300 \mu \mathrm{L}$ of $0.56 \%$ (wt/vol) meta-phosphoric acid (33.5-36.5\%, Sigma-Aldrich), and HPLC-grade water (Fluka) was then added. Samples were shaken for $30 \mathrm{~s}$ and centrifuged in a microcentrifuge at $12,000 \times g$ for $10 \mathrm{~min}$ to separate fat and protein from the aqueous phase. All samples were then filtered through a $0.45-\mu \mathrm{m}$ cellulose filter (VWR) and analyzed by HPLC (Breeze 2 system, Waters Corporation, Milford, MA) with a reversed-phase column (Kinelex $5 \mathrm{u} \mathrm{XB- \textrm {C } _ { 1 8 }} 100 \times 4.60$ $\mathrm{mm}$, Phenomenex). Thirty microliters of sample was injected with a flow rate of $0.7 \mathrm{~mL} / \mathrm{min}$, with a mobile phase composed of HPLC-grade water with $0.1 \%$ acetic acid (Sigma-Aldrich) and methanol (HPLC grade, Fluka) at a concentration of $(95: 5 \mathrm{vol} / \mathrm{vol})$. Samples were analyzed using a Waters 2998 pathodiode array detector with a wavelength of $254 \mathrm{~nm}$. Ascorbic acid concentration was determined based on a 7-point standard curve derived from an L-ascorbic acid standard ( $\geq 99.0 \%$ purity, Sigma-Aldrich). All whey samples were extracted in triplicate and each extraction was injected in duplicate.

\section{a-Tocopherol Determination}

$\alpha$-Tocopherol and was quantified by HPLC as outlined by Salo-Väänänen et al. (2000) with minor modifications. First, liquid and rehydrated samples $(5.0 \pm$ $0.2 \%$ solids) were thermostated at $40^{\circ} \mathrm{C}$ to stabilize fat distribution for $30 \mathrm{~min}$. One gram of each sample was then added to a container with $0.5 \mathrm{~g}$ of $98.5 \%$ pyrogallol (Sigma-Aldrich) and $0.5 \mathrm{~g}$ of $95 \%$ ascorbic acid (SigmaAldrich) before being capped, vortexed, and allowed to stand for $10 \mathrm{~min}$. The container was nitrogen flushed after the addition of $0.5 \mathrm{~mL}$ of $50 \% \mathrm{KOH}$. The tube was capped and transferred to a boiling water bath for $20 \mathrm{~min}$ and shaken once after $10 \mathrm{~min}$. The tube was then cooled in an ice-water bath for $10 \mathrm{~min}$, and 6 $\mathrm{mL}$ of a $(8: 1: 1, \mathrm{vol} / \mathrm{vol})$ solution of water, hexane, and ethyl acetate (Sigma-Aldrich) was added. The tubes were then shaken and centrifuged for $10 \mathrm{~min}$ at 800 $\times g$. This extraction was repeated 2 more times with $2 \mathrm{~mL}$ of the water-hexane-ethyl acetate solution, and the combined organic phase was evaporated to dryness under nitrogen before being reconstituted in $1 \mathrm{~mL}$ of a THF-methanol complex (20:80 vol/vol). Samples were then filtered through a nylon $0.20-\mu \mathrm{m}$ filter (VWR) and $30 \mu \mathrm{L}$ was injected onto an HPLC unit with a reversed-phase column (Kinelex $5 \mathrm{u} \mathrm{XB- \textrm {C } _ { 1 8 }} 100 \times 4.60$ $\mathrm{mm}$, Phenomenex). Aliquots of each sample were then quantified with a mobile phase composed of $10 \%$ THF, $90 \%$ methanol, and $0.5 \mathrm{~g} / \mathrm{L}$ butylated hydroxytoluene. Column temperature was maintained at $30^{\circ} \mathrm{C} \pm 0.4^{\circ} \mathrm{C}$ and flow rate was maintained at $0.7 \mathrm{~mL} / \mathrm{min}$. Peaks were analyzed using a Waters 2998 pathodiode array detector set at $265 \mathrm{~nm}$ for vitamin D and $292 \mathrm{~nm}$ for $\alpha$-tocopherol. Vitamin concentration was determined based on standard curves composed of 6 concentrations of $\geq 99.0 \% \alpha$-tocopherol (Sigma-Aldrich), and $\geq 99.0 \%$ cholecalciferol (Sigma-Aldrich).

\section{Thiamin, Riboflavin, Nicotinic Acid, Pantothenic Acid, and Cobalamin Determination}

Thiamin, riboflavin, nicotinic acid, pantothenic acid, and cobalamin were determined chromatographically in triplicate as outlined by Agostini-Costa et al. (2007). A 5- to 8-mL portion of liquid or rehydrated sample $(5.0 \pm 0.2 \%$ solids $)$ was placed into a flask containing $45 \mathrm{~mL}$ of $0.1 \mathrm{~N}$ sulfuric acid (Fluka). The solution was mixed on an oscillating plate mixer at 180 rotations/ min for $1 \mathrm{~h}$. This complex was then transferred to a 100-mL volumetric flask and brought to volume with methanol before being filtered through a $0.45-\mu \mathrm{m}$ cellulose filter and analyzed by HPLC (Breeze 2 system, Waters Corp.) with a reversed-phase column (Kinelex $5 \mathrm{u}$ XB-C18 $100 \times 4.60 \mathrm{~mm}$, Phenomenex). Twenty 
microliters of sample was injected at a flow rate of 1.0 $\mathrm{mL} / \mathrm{min}$, implementing a gradient of 2 mobile phases. The aqueous phase consisted of $2 \%$ acetonitrile and $0.15 \%$ trimethylamine (Sigma-Aldrich) in $5 \mathrm{mmol} / \mathrm{L}$ hexanesulfonic acid (EMD Millipore, Darmstadt, Germany), and $87.85 \%$ HPLC-grade water adjusted to $\mathrm{pH}$ 2.8 with $0.1 \mathrm{~N} \mathrm{H}_{2} \mathrm{SO}_{4}$. The organic phase was $100 \%$ HPLC-grade methanol. The gradient was programmed to begin with $100 \%$ aqueous phase for $3 \mathrm{~min}$, followed by a linear progression to $43 \%$ aqueous phase and $57 \%$ organic phase at $23 \mathrm{~min}$. Following this gradient, the machine was programmed to return to $100 \%$ aqueous phase by minute 35 and allowed to equilibrate until minute 55, at which point another sample could be injected onto the column. Peaks were analyzed using a Waters 2998 pathodiode array detector measuring wavelengths 254, 278, and $358 \mathrm{~nm}$. Peak identification and compound concentration were determined based on individual standard curves derived from standards for each compound. Vitamin concentration was determined based on a standard curves composed of 6 concentrations of $\geq 99.0 \%$ thiamin (Sigma-Aldrich), $\geq 98.0 \%$ riboflavin (Supelco, Bellefonte, PA), $\geq 99.5 \%$ nicotinic acid (Sigma-Aldrich), D-pantothenic acid $\geq 99 \%$ (Sigma-Aldrich), and $\geq 98.0 \%$ cyanocobalamin (Sigma-Aldrich). Compounds were evaluated from each sample in duplicate.

\section{Volatile Compound Analysis}

Volatile compounds were determined in triplicate by GC-MS after extraction by headspace solid-phase microextraction as outlined by Campbell et al. (2011). Spray-dried WPC80 samples were rehydrated to $10 \%$ (wt/vol) solids, with $10 \%$ (wt/vol) $\mathrm{NaCl}$ (VWR) and $5 \mu \mathrm{L}$ of an internal standard composed of $8.1 \mathrm{mg} / 100$ $\mathrm{mL}$ 2-methyl-3-heptanone in HPLC-grade ether (Sigma-Aldrich). Samples were maintained at $10^{\circ} \mathrm{C}$ before fiber exposure. Samples were equilibrated at $40^{\circ} \mathrm{C}$ for $25 \mathrm{~min}$ before a 30 -min exposure to a 1 -cm tri-phase (divinylbenzene/carboxen/polydimethylsiloxane) fiber (Supelco) at $31 \mathrm{~mm}$ with 4 -s pulsed agitation at 250 rpm. Fibers were injected at a depth of $50 \mathrm{~mm}$ for 5 min. Sampling injections and equilibrations were done by use of a CombiPal Autosampler (CTC Analytics, Zwingen, Switzerland). The column used was an Rtx-5ms column (Rtx- $5 \mathrm{mn}, 30 \mathrm{~m} \times 0.25 \mathrm{~mm}$ i.d. $\times$ $0.25-\mu \mathrm{m}$ film thickness; Restek, Bellefonte, PA). The initial GC temperature was maintained at $40^{\circ} \mathrm{C}$ for 3 min, increased to $90^{\circ} \mathrm{C}$ at a rate of $10^{\circ} \mathrm{C} / \mathrm{min}$, and then increased to $200^{\circ} \mathrm{C}$ at a rate of $5^{\circ} \mathrm{C} / \mathrm{min}$. This temperature was held for $10 \mathrm{~min}$, increased to $250^{\circ} \mathrm{C}$ at a rate of $20^{\circ} \mathrm{C} / \mathrm{min}$, and then held for $5 \mathrm{~min}$. The fibers were introduced into the split/splitless injector while the column was maintained at $250^{\circ} \mathrm{C}$. The MS source and transfer line were maintained at $250^{\circ} \mathrm{C}$ with the quadrupole at $150^{\circ} \mathrm{C}$. Compounds were identified using the National Institute of Standards and Technology (2014) mass spectral database. Internal standard concentration was used to calculate the relative abundance of selected compounds (Jervis et al., 2012; Campbell and Drake, 2013b).

\section{Descriptive Sensory Analysis}

Descriptive sensory analysis of rehydrated WPC80 was conducted by a trained sensory panel $(n=8)$ in compliance with the NCSU Institutional Review Board for Human Subjects approval. Panelists were between the ages of 23 and $50 \mathrm{yr}$, and each had over $150 \mathrm{~h}$ of experience in descriptive analysis of dried dairy ingredients using the Spectrum descriptive analysis method and a 0 - to 15 -point universal intensity scale (Drake and Civille, 2003; Meilgaard et al., 2007). Powders were rehydrated to $10 \%$ solids (wt/vol) in deionized water, and descriptive analysis used a previously published lexicon for dried dairy ingredients (Drake et al., 2003, 2009; Wright et al., 2009). Samples (40 mL) were dispensed without overhead lighting into 59-mL soufflé cups (Solo Cup Co., Champaign, IL), lidded, given a randomized 3 -digit code, and allowed to temper to $21^{\circ} \mathrm{C}$. Panelists expectorated each sample and were provided deionized water for palate cleansing. Each sample from each experimental replicate was evaluated by each panelist in duplicate. Compusense Cloud version 7.8 (Compusense, Guelph, ON, Canada) was used for data collection.

\section{Statistical Analyses}

Data were analyzed by ANOVA with means separation using XLSTAT software (version 2015.3.01; Addinsoft, New York, NY). Fisher's least significant difference (LSD) test was used to analyze differences among sample means $(\alpha=95 \%)$.

\section{RESULTS AND DISCUSSION}

\section{Compositional Analysis}

Fat concentrations of liquid whey before fat separation, following fat separation, and following ultrafiltration were $0.190 \% \pm 0.042,0.073 \% \pm 0.052$, and $0.3814 \% \pm 0.073$, respectively. Percent solids of liquid whey before separation, whey after fat separation, and whey following ultrafiltration were $6.87 \% \pm 0.62,6.40 \%$ \pm 0.71 , and $10.32 \% \pm 0.65$, respectively. Fat content of powdered WPC 80 was $3.87 \% \pm 0.53$, moisture was $4.69 \% \pm 0.68$, and protein content was $81.3 \% \pm 0.95$. 
Calcium, potassium, magnesium, sodium, and phosphorus concentrations of powdered WPC80 were not different $(P>0.05)$ and were consistent with previous studies (Jervis et al., 2012; Campbell et al., 2014; Smith et al., 2015; results not shown). The mean concentration of iron was significantly lower $(P<0.05)$ in powdered WPC80 bleached with HP or LP compared with powdered WPC80 Con, AltC, and BP (7.48 \pm 0.82 vs. $11.49 \pm 1.16 \mathrm{mg} / \mathrm{kg}$, respectively), which was consistent with previous research (Jervis et al., 2012).

\section{Vitamin Loss During Processing}

Degradation of fat-soluble compounds in WPC80 (Table 2) was induced by bleaching; however, over $90 \%$ of fat-soluble compound loss occurred during curd formation and cream separation (stages 2 and 3 respectively, Figure 1). Because these vitamins are primarily found in milk fat, fat-soluble vitamin loss during these stages was likely because these processes reduce the concentration of fat in whey (Bilic and Sieber, 1988; Batra et al., 1992). Consistent with previous research, retinol, $\beta$-carotene, and $\alpha$-carotene were not affected $(P$ $>0.05$ ) by whey pasteurization (Bilic and Sieber, 1988; Jesse, 1985). Pasteurization of whey caused $3.2 \%$ degradation to $\alpha$-tocopherol $(P<0.05)$, which is comparable to $\alpha$-tocopherol degradation during milk pasteurization (MacDonald et al., 2011). Ultrafiltration and spray drying also did not affect the concentration of fat-soluble compounds $(P>0.05$, Labuza and Tannenbaum, 1972). The WPC80 colored with AltC contained $6.2 \%$ more $\beta$-carotene than uncolored Con WPC80 (0.065 vs. $0.061 \mathrm{mg} / \mathrm{kg} ; P<0.05)$, indicating that $<1.0 \%$ of the added $\beta$-carotene-based alternative cheese colorant was present in the final whey. As with other fat-soluble compounds, the majority of the $\beta$-carotene in AltC samples was lost during curd formation.

Consistent with previous literature, water-soluble vitamins in powdered WPC80 had less than $20 \%$ degradation compared with pasteurized milk, except for ascorbic acid and thiamin, which were reduced from 1.24 to $0.71 \mu \mathrm{g} / 100 \mathrm{~mL}$ and from 43.7 to $33.06 \mu \mathrm{g} / 100$ $\mathrm{mL}$ respectively (Sierra and Vidal-Valverde, 2001; Ottaway, 2002; MacDonald et al., 2011). Concentrations of ascorbic acid in liquid whey decreased during whey pasteurization and bleaching (stages 4 and 5 respectively; $P<0.05$ ). Although ascorbic acid is heat labile, bleaching caused much more degradation (1.14 to 0.74 $\mathrm{mg} / 100 \mathrm{~mL}$ ) than pasteurization (1.18 to $1.14 \mathrm{mg} /$ $\mathrm{mL} ; P<0.05)$. Concentrations of cobalamin decreased by $10.2 \%$ following whey pasteurization (stage $4 ; P<$ 0.05). A meta-analysis by MacDonald et al. (2011) indicated that ascorbic acid, thiamin, and cobalamin are all heat-labile and susceptible to degradation during milk pasteurization. Similar heat degradation was observed in liquid whey.

\section{Bleaching Treatments}

The concentrations of fat-soluble vitamins immediately before bleaching of each sample were compared with concentration of fat-soluble vitamins immediately after bleaching (Figure 2). Liquid whey treated with HP, LP, or BP had lower concentrations of all measured fat-soluble vitamins after bleaching compared with concentrations before bleaching $(P<0.05)$, indicating that bleaching negatively affected fat-soluble vitamins. Because retinol, $\alpha$-tocopherol, $\beta$-carotene, and

Table 2. Vitamin and carotenoid concentrations before and after bleaching treatments ${ }^{1}$

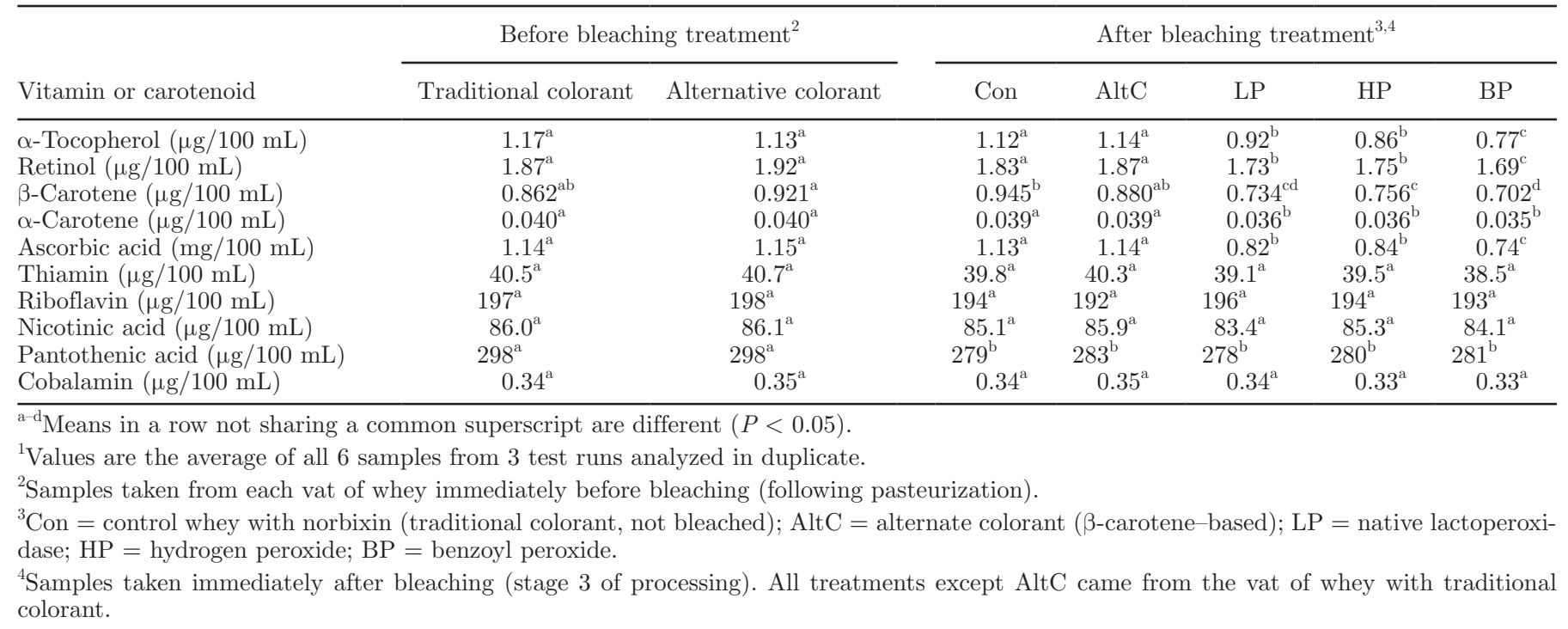


$\alpha$-tocopherol are prone to oxidative degradation, these results were expected (Barrefors et al., 1995; KamalEldin and Appelqvist, 1996; Henry et al., 1998).

The concentration of $\beta$-carotene before and after bleaching in liquid wheys indicated more than $12 \%$ degradation by bleaching, with BP bleaching causing the most dramatic degradation $(17.4 \% ; P<0.05)$. Similar results were observed for $\alpha$-tocopherol, retinol, and $\alpha$-carotene before and after bleaching $(P<0.05$; McCay, 1985; Kamal-Eldin and Appelqvist, 1996). This could be because formation of free radicals during benzoyl peroxide bleaching is encouraged due to charge stabilization along the benzene ring during hemolysis (Murakami et al., 1985). Stabilization of free radicals contributes to a lower bond dissociation energy of the $\mathrm{O}-\mathrm{O}$ bond of $\mathrm{BP}\left(36.9 \mathrm{kcal} / \mathrm{mol}\right.$ at $\left.25^{\circ} \mathrm{C}\right)$ compared with the $\mathrm{O}-\mathrm{O}$ bond of $\mathrm{HP}\left(50.5 \mathrm{kcal} / \mathrm{mol}\right.$ at $25^{\circ} \mathrm{C}$; Bach et al., 1996), which allows for greater bleaching potential and greater oxidation in general than HP or hypothiocyanate (the peroxide formed during LP bleaching). Additionally, BP is more nonpolar than HP or hypothiocyanate and might bleach fat-soluble compounds more readily as it solubilizes along the surface of fat globules (Jervis et al., 2012). Bleaching efficiency of BP in fat was expected, as well as destruction of natural carotenoids, as BP has been used to bleach native carotenoids in milk fat during blue cheese production (Washam et al., 1974).

No difference in $\alpha$-carotene degradation was observed among bleaching agents $(P>0.05)$. Bleaching caused greater degradation to $\alpha$-tocopherol $(P<0.05)$ than any other compound tested with degradation of 25.9 ,

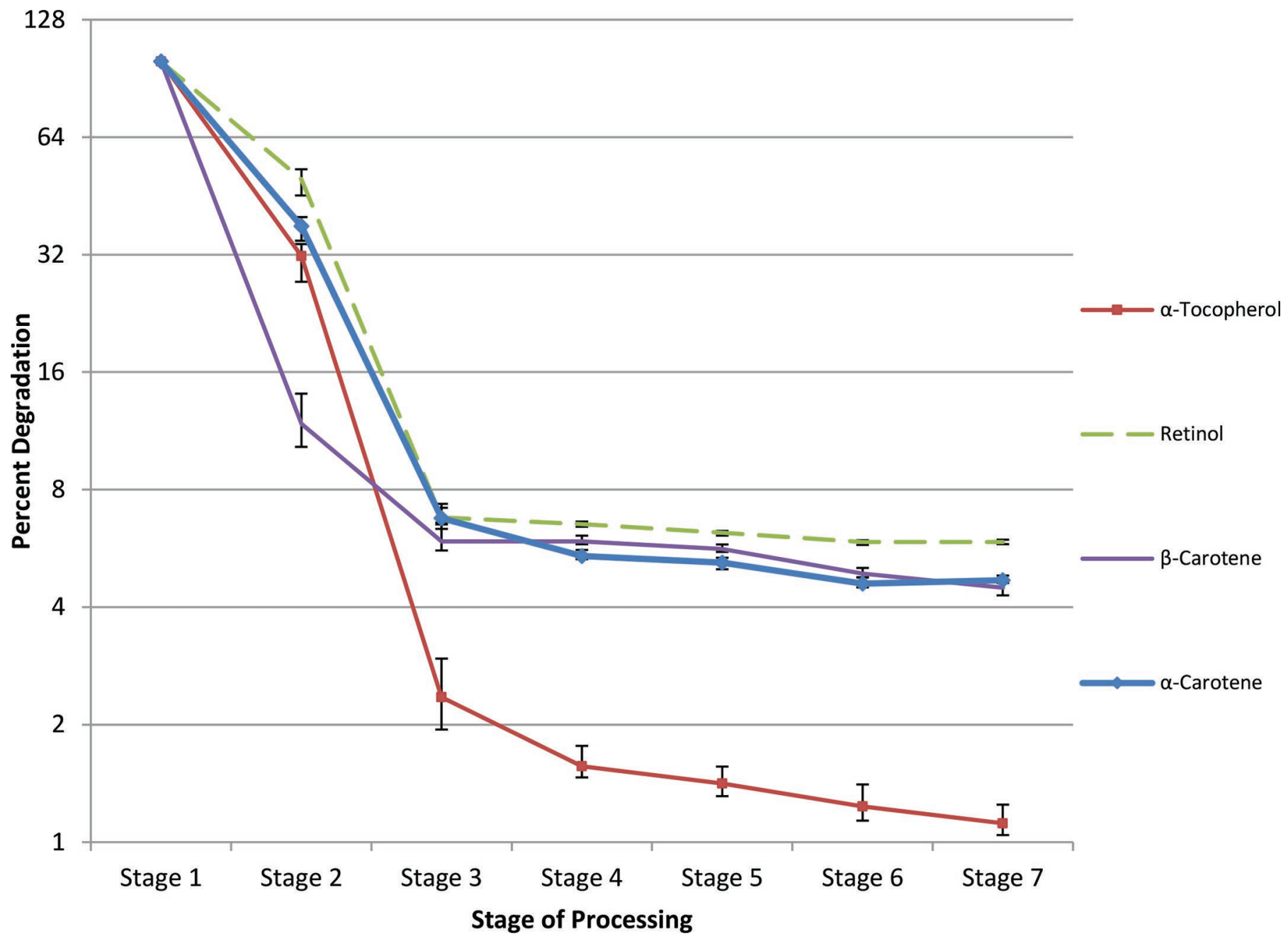

Figure 1. Mean percentage of fat-soluble vitamin loss throughout processing of control (Con) whey (unbleached whey with traditional annatto colorant). Percentage degradation indicates the percentage of starting compound (measured in stage 1) measured during each stage. Values are represented as the mean of all 3 replications measured in duplicate $(n=6)$. Error bars represent SD. Color version available online. 


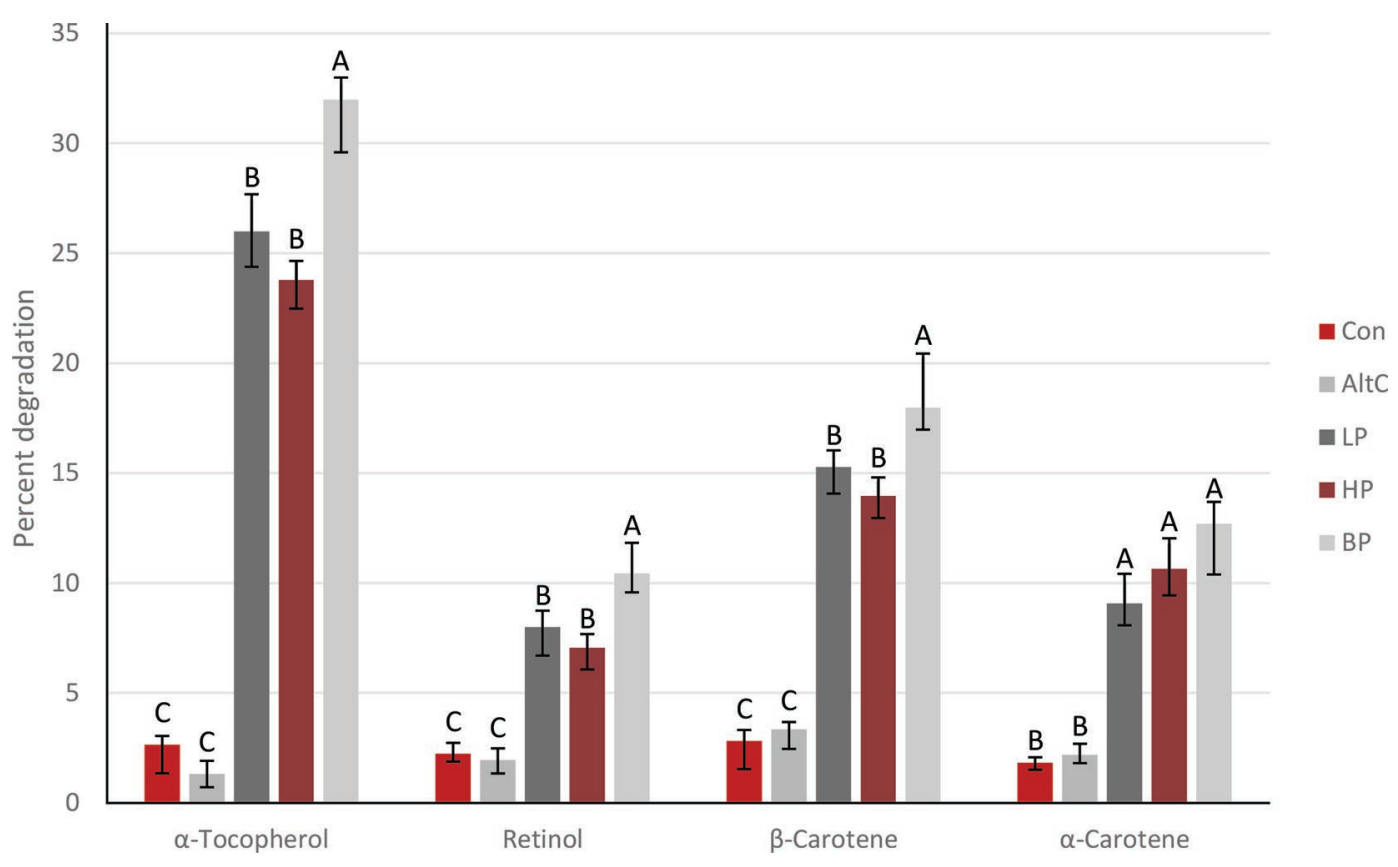

Figure 2. Mean percentage degradation of fat-soluble compounds in liquid whey after bleaching treatment relative to concentrations before bleaching. Mean percent degradation was determined by the ratio of the mean $(n=6)$ concentration at stage 5 of processing compared with the mean $(\mathrm{n}=6)$ concentration at stage 4 of processing for each compound (Table 1 ). Means within a compound not sharing a common letter $(\mathrm{A}-\mathrm{C})$ are different $(P<0.05)$. Con $=$ control whey with norbixin (traditional colorant, not bleached); AltC $=$ alternate colorant $(\beta$-carotenebased); $\mathrm{LP}=$ native lactoperoxidase; $\mathrm{HP}=$ hydrogen peroxide; $\mathrm{BP}=$ benzoyl peroxide. Error bars represent $\mathrm{SD}$. Color version available online.

23.8 , and $31.9 \%$ for LP, HP, and BP, respectively. This was expected, as $\alpha$-tocopherol has been demonstrated to be an antioxidant, which is more efficient at free radical scavenging during lipid peroxidation than retinol or $\beta$-carotene (Vile and Winterbourn, 1988). We detected no difference $(P>0.05)$ between concentrations of fat-soluble compounds before and after the bleaching step (stage 5) for Con and AltC. These samples were not subjected to a bleaching agent during this step but were held at $50^{\circ} \mathrm{C}$ for $1 \mathrm{~h}$.

Bleaching liquid whey did not affect concentrations of thiamin, riboflavin, nicotinic acid, pantothenic acid, or cobalamin $(P>0.05$; Table 2$)$. Compounds such as thiamin and riboflavin are prone to oxidation but often require a catalyst to oxidize significantly under the conditions seen in milk (Frisell et al., 1959; Lukienko et al., 2000). However, bleaching liquid whey with LP, HP, and BP caused 28.2, 26.4, and 35.0\% degradation to ascorbic acid, respectively $(P<0.05)$. As with fatsoluble compound degradation, degradation of ascorbic acid did not differ between LP- and HP-bleached liquid whey $(P>0.05)$, whereas BP bleaching caused more degradation to liquid whey than HP or LP $(P<0.05)$. This was expected as natural oxidation of ascorbic acid in dairy products before the introduction of any proxidant has been well documented (Smith and Dunkley 1961; Zulueta et al., 2007).
Concentrations of thiamin, riboflavin, nicotinic acid, and cobalamin did not differ in Con or AltC wheys following $1 \mathrm{~h}$ at $50^{\circ} \mathrm{C}(P>0.05$, Table 2$)$. This result suggests that heating liquid whey to $50^{\circ} \mathrm{C}$ for $1 \mathrm{~h}$ did not affect the concentrations of these water-soluble vitamins. Concentrations of pantothenic acid were reduced by 5.6 and $4.2 \%$ in Con and AltC wheys, respectively, following $1 \mathrm{~h}$ at $50^{\circ} \mathrm{C}(P>0.05)$. No differences were observed in pantothenic acid degradation between treatments that used bleach and those that did not during this stage $(P>0.05)$. Consistent with previous research, this finding indicates that the $50^{\circ} \mathrm{C}$ heat treatment for $1 \mathrm{~h}$ was likely responsible for the observed pantothenic acid degradation (Ottaway, 1993).

Vitamin degradation in WPC80 due to bleaching has little to no effect on nutrition labeling. Riboflavin, thiamin, niacin, cobalamin, and pantothenic acid concentrations were not affected by bleaching. Retinol, $\beta$-carotene, $\alpha$-carotene, and $\alpha$-tocopherol concentrations were affected by bleaching, but vitamin $\mathrm{A}$ and E concentrations were below $1 \%$ of the recommended daily value (DV) for a typical serving size of $25 \mathrm{~g}$ (FDA, 2016). Vitamin $\mathrm{C}$ was found at a concentration (2.3-3.1\% DV for a 252-g serving), which could be labeled in the nutrition facts panel (FDA, 2016). Bleaching of WPC80 caused a roughly 1 percentage point reduction in the reported DV for vitamin $\mathrm{C}$ in 
WPC80. Differences between bleaching agents would not affect the percentage DV for vitamin C in WPC80 due to rounding rules (FDA, 2016).

\section{Bleaching Efficacy}

Treatment of liquid whey with LP or BP resulted in greater norbixin degradation $(\geq 95 \%)$ than bleaching with HP $(54.6 \% ; P<0.05)$, consistent with previous research (Campbell and Drake, 2013b, 2014; Fox et al., 2013; Jervis and Drake, 2013; Smith et al., 2015). All measured values were consistent with results reported in previous research (Campbell and Drake, 2013b; Fox et al., 2013; Smith et al., 2015). It should be noted that although LP bleaching caused more norbixin degradation than HP bleaching, LP bleaching caused similar degradation of fat-soluble vitamins to HP bleaching $(P>0.05)$. The primary objective of this study was to determine the effects of current bleaching practices on vitamin concentrations. Thus, we used concentrations of LP, BP, and HP that represent moderate to high concentrations used by industry, consistent with previous studies. Just as bleach concentrations, temperatures, and time can be optimized to minimize off-flavors and maximize norbixin destruction, it might be possible to optimize bleach conditions to minimize vitamin destruction. Future work is needed to address the optimal dose-response relationship to optimize norbixin degradation and limit vitamin degradation for each bleaching agent.

\section{Descriptive Sensory and Instrumental Volatile Analysis}

The 2 control WPC80 (Con and AltC) did not have distinct flavor profiles $(P>0.05)$. Consistent with previous studies, bleached WPC80 had higher cardboard flavor than Con or AltC WPC80 (mean score $=0.8$ vs. 2.0, respectively; $P<0.05$ ) and lower sweet aromatic flavor than Con or AltCWPC80 (mean score $=1.1$ vs. 1.7 respectively; $P<0.05$ ) (Jervis et al., 2012; Smith et al., 2015). The LP WPC 80 had a low but distinct cabbage flavor (mean score $=1.2$ ) not documented in other bleached or unbleached WPC80. Campbell and Drake (2013b) also documented a cabbage flavor in WPC80 from LP-bleached fluid whey.

Consistent with sensory results, we detected no differences in the volatile compound profiles of Con and AltC WPC80 $(P>0.05$; Table 3$)$. Bleached WPC80 had higher concentrations of many volatile lipid oxidation compounds compared with Con or AltC WPC80, consistent with previous bleaching studies (Croissant et al., 2009; Jervis et al., 2012; Campbell and Drake, 2013b; Fox et al., 2013; Smith et al., 2015). Volatile compound profiles of the 3 bleached WPC80 were distinct, which was also consistent with previous research.

\section{CONCLUSIONS}

To ensure high-quality product, it is important that WPC80 be colorless. Both chemical and enzymatic

Table 3. Mean relative abundance $(\mu \mathrm{g} / \mathrm{kg})$ of selected volatile compounds in powdered whey protein concentrate $80 \%$ protein

\begin{tabular}{|c|c|c|c|c|c|}
\hline \multirow[b]{2}{*}{ Volatile compound } & \multicolumn{5}{|c|}{ Treatment $^{1}$} \\
\hline & Con & AltC & LP & $\mathrm{HP}$ & $\mathrm{BP}$ \\
\hline Hexanal & $0.18^{\mathrm{c}}$ & $0.17^{\mathrm{c}}$ & $3.9^{\mathrm{a}}$ & $1.10^{\mathrm{b}}$ & $0.50^{\mathrm{b}}$ \\
\hline Heptanal & $0.09^{\mathrm{c}}$ & $0.12^{\mathrm{c}}$ & $1.5^{\mathrm{a}}$ & $0.77^{\mathrm{b}}$ & $0.25^{\mathrm{c}}$ \\
\hline Octanal & $0.098^{\mathrm{c}}$ & $0.074^{\mathrm{c}}$ & $8.91^{\mathrm{a}}$ & $8.86^{\mathrm{a}}$ & $4.29^{\mathrm{b}}$ \\
\hline Nonanal & $2.73^{\mathrm{c}}$ & $3.35^{\mathrm{c}}$ & $7.84^{\mathrm{a}}$ & $7.13^{\mathrm{b}}$ & $4.79^{\mathrm{b}}$ \\
\hline Diacetyl & $0.644^{\mathrm{ab}}$ & $0.734^{\mathrm{a}}$ & $0.577^{\mathrm{b}}$ & $0.651^{\mathrm{ab}}$ & $0.526^{\mathrm{b}}$ \\
\hline Decanal & $0.251^{\mathrm{b}}$ & $0.227^{\mathrm{b}}$ & $0.402^{\mathrm{a}}$ & $0.379^{\mathrm{a}}$ & $0.234^{\mathrm{b}}$ \\
\hline Benzaldehyde & $0.214^{\mathrm{a}}$ & $0.186^{\mathrm{a}}$ & $0.326^{\mathrm{a}}$ & $0.206^{\mathrm{a}}$ & $0.255^{\mathrm{a}}$ \\
\hline Dimethyl trisulfide & $0.039^{\mathrm{c}}$ & $0.020^{\mathrm{c}}$ & $0.087^{\mathrm{a}}$ & $0.051^{\mathrm{b}}$ & $0.054^{\mathrm{b}}$ \\
\hline Acetic acid & $0.316^{\mathrm{c}}$ & $0.322^{\mathrm{c}}$ & $0.401^{\mathrm{a}}$ & $0.379^{\mathrm{b}}$ & $0.319^{\mathrm{c}}$ \\
\hline 2-Pentyl furan & $34.5^{\mathrm{d}}$ & $31.6^{\mathrm{d}}$ & $201^{\mathrm{b}}$ & $149^{\mathrm{c}}$ & $341^{\mathrm{a}}$ \\
\hline 1-Hexen-3-one & $0.467^{\mathrm{c}}$ & $0.382^{\mathrm{c}}$ & $0.903^{\mathrm{b}}$ & $1.82^{\mathrm{a}}$ & $0.69^{\mathrm{bc}}$ \\
\hline 1-Pentanol & $1.35^{\mathrm{b}}$ & $0.89^{\mathrm{c}}$ & $4.13^{\mathrm{a}}$ & $3.79^{\mathrm{a}}$ & $1.21^{\mathrm{bc}}$ \\
\hline 1-Octen-3-one & $0.03^{\mathrm{c}}$ & $0.09^{\mathrm{c}}$ & $0.62^{\mathrm{a}}$ & $0.42^{\mathrm{b}}$ & $0.11^{\mathrm{c}}$ \\
\hline Dimethyl disulfide & $0.002^{\mathrm{c}}$ & $0.006^{\mathrm{b}}$ & $0.012^{\mathrm{a}}$ & $0.008^{\mathrm{ab}}$ & $0.005^{\mathrm{b}}$ \\
\hline 3-Methylbutanal & $0.634^{\mathrm{a}}$ & $0.726^{\mathrm{a}}$ & $0.573^{\mathrm{a}}$ & $0.711^{\mathrm{a}}$ & $0.561^{\mathrm{a}}$ \\
\hline 2-E-Octenal & $5.42^{\mathrm{a}}$ & $2.25^{\mathrm{b}}$ & $5.08^{\mathrm{a}}$ & $6.87^{\mathrm{a}}$ & $2.96^{\mathrm{b}}$ \\
\hline 2-Methylbutanal & $1.14^{\mathrm{ab}}$ & $1.2^{\mathrm{ab}}$ & $1.40^{\mathrm{b}}$ & $1.37^{\mathrm{b}}$ & $0.89^{\mathrm{a}}$ \\
\hline 2,3-Octanedione & $1.43^{\mathrm{a}}$ & $0.634^{\mathrm{c}}$ & $1.01^{\mathrm{b}}$ & $1.12^{\mathrm{ab}}$ & $0.891^{b c}$ \\
\hline
\end{tabular}

${ }^{\mathrm{a}-\mathrm{d}}$ Means in a row not sharing a common superscript are different $(P<0.05)$.

${ }^{1} \mathrm{Con}=$ control whey with norbixin (traditional colorant, not bleached); AltC $=$ alternate colorant $(\beta$-carotenebased); $\mathrm{LP}=$ native lactoperoxidase; $\mathrm{HP}=$ hydrogen peroxide; $\mathrm{BP}=$ benzoyl peroxide. 
bleaching degrade vitamins and carotenoids native to fluid milk and WPC80. Vitamins and carotenoids affected by bleaching included $\alpha$-tocopherol, retinol, $\beta$-carotene, $\alpha$-carotene, and ascorbic acid. Water-soluble vitamins thiamin, riboflavin, nicotinic acid, pantothenic acid, and cobalamin were not affected by enzymatic or oxidative bleaching agents. For WPC80 bleaching, BP has established greater bleaching efficiency and lower effects on flavor compared with HP or LP. However, $\mathrm{BP}$ results in greater degradation of vitamins and carotenoids than HP or LP. Enzymatic bleaching with LP can provide similar degradation of the colorant norbixin, while degrading less $\alpha$-tocopherol, retinol, and ascorbic acid than BP. Alternative colorants may provide a solution that allows for colorless WPC80 with minimal off-flavors while also preserving compounds prone to degradation.

\section{ACKNOWLEDGMENTS}

Funding was provided in part by the National Dairy Council (DRI; formerly Dairy Management Inc., Rosemont, IL). The alternative colorant (DairyMax Orange Red 002) was provided by Chr. Hansen, which is gratefully acknowledged. The use of trade names does not imply endorsement or lack of endorsement of any product used.

\section{REFERENCES}

Agostini-Costa, T. S., J. Teixeira-Filho, R. Scherer, C. H. Kowalski, M. A. Prado, and H. T. Godoy. 2007. Determination of B-group vitamins in enriched flavored milk mixes. Alim. Nutr. Araraquara 18:251-256.

AOAC International. 2012. Official Methods of Analysis. 19th ed. AOAC Int., Gaithersburg, MD.

Bach, R. D., P. Y. Ayala, and H. B. Schlegel. 1996. A reassessment of the bond dissociation of energies of peroxides. An ab initio study. J. Am. Chem. Soc. 118:12758-12765.

Barrefors, P., K. Granelli, L. A. Appelqvist, and L. Bjoerck. 1995. Chemical characterization of raw milk samples with and without oxidative off-flavor. J. Dairy Sci. 78:2691-2699.

Batra, T. R., K. Singh, S. K. Ho, and M. Hidiroglou. 1992. Concentration of plasma and milk vitamin $\mathrm{E}$ and plasma $\beta$-carotene of mastitic and healthy cows. Int. J. Vitam. Nutr. Res. 62:233-237.

Bilic, N., and R. Sieber. 1988. Determination of retinol and $\alpha$-tocopherol in raw, pasteurized and cooked milk. Schweiz. Milchwirtsch. Forsch. 17:17.

Campbell, R. E., I. A. L. A. Boogers, and M. A. Drake. 2014. Development of a novel method for the extraction of norbixin from whey and its subsequent quantification via high performance liquid chromatography. J. Dairy Sci. 97:1313-1318.

Campbell, R. E., and M. A. Drake. 2013a. Impact of native and nonnative enzymes on the flavor of dried dairy ingredients. J. Dairy Sci. 96:4773-4783.

Campbell, R. E., and M. A. Drake. 2013b. Cold enzymatic bleaching of fluid whey. J. Dairy Sci. 96:7404-7413.

Campbell, R. E., and M. A. Drake. 2014. Enzymatic bleaching in commercial colored cheddar whey retentates. Int. Dairy J. 38:148-153.

Campbell, R. E., E. J. Kang, E. Bastian, and M. A. Drake. 2012. The use of lactoperoxidase for the bleaching of fluid whey. J. Dairy Sci. $95: 2882-2890$.
Campbell, R. E., R. E. Miracle, P. D. Gerard, and M. A. Drake. 2011. Effects of starter culture and storage on the flavor of liquid whey. J. Food Sci. 76:S354-S361.

Candow, D. G., N. C. Burke, T. Smith-Palmer, and D. G. Burthe. 2006. Effect of whey and soy protein supplementation combined with resistance training in young adults. Int. J. Sport Nutr. Exerc. Metab. 16:233-244.

Childs, J. L., J. L. Thompson, J. S. Lillard, T. K. Berry, and M. A. Drake. 2008. Consumer perception of whey and soy protein in meal replacement products. J. Sens. Stud. 23:320-339.

Coker, R. H., S. Miller, S. Schutzler, N. Deutz, and R. R. Wolfe. 2012 Whey protein and essential amino acids promote the reduction of adipose tissue and increased muscle protein synthesis during caloric restriction-induced weight loss in elderly, obese individuals. Nutr. J. 11:105.

Croissant, A. E., E. J. Kang, R. E. Campbell, E. Bastian, and M. A. Drake. 2009. The effect of bleaching agent on the flavor of liquid whey and whey protein concentrate. J. Dairy Sci. 92:5917-5927.

Davis, J. P., and E. A. Foegeding. 2007. Comparisons of the foaming and interfacial properties of whey protein isolate and egg white proteins. Colloid. Surface. B Biointerfaces 54:200-210.

Drake, M. A., and G. V. Civille. 2003. Flavor lexicons. Compr. Rev. Food Sci. Food Saf. 2:33-40.

Drake, M. A., Y. Karagul-Yuceer, K. R. Cadwallader, G. V. Civille, and P. S. Tong. 2003. Determination of the sensory attributes of dried milk powders and dairy ingredients. J. Sens. Stud. 18:199216

Drake, M. A., R. E. Miracle, and J. M. Wright. 2009. Sensory properties of dairy proteins. Pages 429-448 in Milk Proteins: From Expression to Food. A. Thompson, M. Boland, and H. Singh, ed. Elsevier, Amsterdam, the Netherlands.

FDA. 2016. 21CFR $\S 101.9$, Title 21, Vol. 2. Food Labeling. https:// www.accessdata.fda.gov/scripts/cdrh/cfdocs/cfcfr/CFRSearch .cfm?fr $=101.9$.

Foegeding, E. A., J. P. Davis, D. Doucet, and M. K. McGuffey. 2002. Advances in modifying and understanding whey protein functionality. Trends Food Sci. Technol. 13:151-159.

Foegeding, E. A., P. J. Luck, and J. P. Davis. 2006. Factors determining the physical properties of protein foams. Food Hydrocoll. $20: 284-292$.

Fox, A. J., T. J. Smith, P. D. Gerard, and M. A. Drake. 2013. The influence of bleaching agent and temperature on bleaching efficacy and volatile components of fluid whey and whey retentate. J. Food Sci. 78:C1535-C1542.

Frisell, W. R., C. W. Chung, and C. G. Machkenzie. 1959. Catalysis of oxidation of nitrogen compounds by Flavin coenzymes in the presence of light. J. Biol. Chem. 234:1297-1302.

Gbassi, G. K., T. Vandamme, S. Ennahar, and E. Marchioni. 2009. Microencapsulation of Lactobacillus plantarum spp in an alginate matrix coated with whey proteins. Int. J. Food Microbiol. 129:103105.

Giuliano, A. R., E. M. Neilson, B. E. Kelly, and L. M. Canfield. 1992. Simultaneous quantitation and separation of carotenoids and retinol in human milk by high-performance liquid chromatography. Methods Enzymol. 213:391-399.

Graf, S., S. Egert, and M. Heer. 2011. Effects of whey protein supplements on metabolism: Evidence from human intervention studies. Curr. Opin. Clin. Nutr. Metab. Care 14:569-580.

Guo, X. X., W. Hu, Y. Liu, S. Sun, D. Gy, H. He, C. Xu, and X. Wang. 2016. Rapid determination and chemical change tracking of benzoyl peroxide in wheat flour by multi-step IR macro-fingerprinting. Spectrochim. Acta A Mol. Biomol. Spectrosc. 154:123-129.

Henry, L. K., G. L. Catignani, and S. J. Schwartz. 1998. Oxidative degradation kinetics of lycopene, lutein, and 9-cis and all-trans $\beta$-carotene. J. Am. Oil Chem. Soc. 75:823-829.

Jervis, M. G., T. J. Smith, and M. A. Drake. 2015. The influence of solids concentration and bleaching agent on bleaching efficacy and flavor of sweet whey powder. J. Dairy Sci. 98:2294-2302.

Jervis, S., R. Campbell, K. L. Wojciechowski, E. A. Foegeding, M. A. Drake, and D. M. Barbano. 2012. Effect of bleaching whey on sen- 
sory and functional properties of $80 \%$ whey protein concentrate. J. Dairy Sci. 95:2848-2862.

Jervis, S. M., and M. A. Drake. 2013. The impact of iron on the bleaching efficacy of hydrogen peroxide in liquid whey systems. J. Food Sci. 78:R129-R137.

Jesse, F. G. 1985. Chemical changes of vitamins during food processing. Pages 373-408 in Chemical Change during Food Processing. J. Davídek, J. Velíšek, and J. Pokorný, ed. Elsevier, Amsterdam, the Netherlands.

Kamal-Eldin, A., and L. A. Appelqvist. 1996. The chemistry and antioxidant properties of tocopherols and tocotrienols. Lipids 31:671701

Kang, E. J., R. E. Campbell, E. Bastian, and M. A. Drake. 2010. Annatto usage and bleaching in dairy foods. J. Dairy Sci. 93:38913901.

Kang, E. J., T. J. Smith, and M. A. Drake. 2012. Alternative bleaching methods for cheddar cheese whey. J. Food Sci. 77:C818-C823.

Labuza, T. P., and S. R. Tannenbaum. 1972. Nutrient losses during drying and storage of dehydrated foods. CRC Crit. Rev. Food Technol. 3:217-240.

Lukienko, P. I., N. G. Mel'nichenko, and I. V. Zverinskii. 2000. Antioxidant properties of thiamine. Bull. Exp. Biol. Med. 130:874-876.

MacDonald, L. E., J. Brett, D. Kelton, S. E. Maiowicz, K. Snedeker, and J. M. Sargeant. 2011. A systemic review and meta-analysis of the effects of pasteurization on milk vitamins, and evidence for raw milk consumption and other health-related outcomes. J. Food Prot. 74:1814-1832.

McCay, P. B. 1985. Vitamin E: Interactions with free radicals and ascorbate. Annu. Rev. Nutr. 5:323-340.

Meilgaard, M. C., G. V. Civille, and B. T. Carr. 2007. The Spectrum ${ }^{\mathrm{TM}}$ descriptive analysis method. Pages 189-253 in Sensory Evaluation Techniques. CRC Press, Boca Raton, FL.

Murakami, K., T. Sano, S. Tsuchie, and T. Yasunaga. 1985. Mechanism of the binding of 2-(4'-hydroxyphenylazo)benzoic acid to bovine serum albumin. Biophys. Chem. 21:127-136.

National Institute of Standards and Technology. 2014. NIST 14 mass spectral library. FarHawk Marketing Services, Evans Mills, NY.

Oltman, A. E., K. Lopetcharat, E. Bastian, and M. A. Drake. 2015. Identifying key attributes for protein beverages. J. Food Sci. 80:S1383-S1390.

Ottaway, P. B. 1993. Stability of vitamins in foods. Pages 90-113 in The Technology of Vitamins in Food. Springer US, Cornwall, UK.

Ottaway, P. B. 2002. The stability of vitamins during food processing. Pages 247-264 in The Nutrition Handbook for Food Processors. C. J. K. Henry and C. Chapman, ed. CRC Press, Boca Raton, FL.

Park, C. W., E. Bastian, B. E. Farkas, and M. A. Drake. 2014. The effect of feed solids concentration and inlet temperature on the flavor of spray dried whey protein concentrate. J. Food Sci. 79:C19-C24.

Romeu-Nadal, M., S. Morera-Pons, A. I. Castellote, and M. C. López Sabater. 2006. Rapid high performance liquid chromatographic method for vitamin $\mathrm{C}$ determination in human milk versus an enzymatic method. J. Chromatogr. B Analyt. Technol. Biomed. Life Sci. 830:41-46.

Salo-Väänänen, P., V. Ollilainen, P. Mattila, K. Lehikoinen, E. Salmela-Mölsäa, and V. Piironen. 2000. Simultaneous HPLC analysis of fat-soluble vitamins in selected animal products after small-scale extraction. Food Chem. 71:535-543.

Scotter, M. 2009. The chemistry and analysis of annatto food coloring: a review. Food Addit. Contam. 26:1123-1145.

Sierra, I., and C. Vidal-Valverde. 2001. Vitamin B1 and B6 retention in milk after continuous-flow microwave and conventional heating at high temperatures. J. Food Prot. 64:890-894.

Sivasankar, B. 2002. Chapter 5: Protein and enxymes. Pages 52-81 in Food Processing and Preservation. 3rd ed. A. Ghosh, ed. PrenticeHall, New Delhi, India.

Smith, G. J., and W. L. Dunkley. 1961. Ascorbic acid oxidation and lipid peroxidation in milk. J. Food Sci. 27:127-134.

Smith, T. J., P. D. Gerard, and M. A. Drake. 2015. Effect of temperature and concentration on benzoyl peroxide bleaching efficacy and benzoic acid levels in whey protein concentrate. J. Dairy Sci. 98:7614-7627

Smith, T. J., X. E. Li, and M. A. Drake. 2014. Norbixin and bixin partitioning in Cheddar cheese and whey. J. Dairy Sci. 97:3321-3327.

USDA. 2010. Dairy Products 2009 Summary. Accessed Sep. 29, 2015. http://usda.mannlib.cornell.edu/usda/nass/DairProdSu//2010s/ 2010/DairProdSu-04-29-2010.pdf.

USDA. 2015. Dairy Products 2014 Summary. Accessed Sep. 29, 2015. http://usda.mannlib.cornell.edu/usda/current/DairProdSu/ DairProdSu-04-29-2015.pdf.

Varnam, A. H., and J. P. Sutherland. 1994. Milk and Milk Products. Chapman and Hall, New York, NY.

Vile, G. F., and C. C. Winterbourn. 1988. Inhibition of Adriamycin-promoted microsomal lipid peroxidation by $\beta$-carotene, $\alpha$-tocopherol and retinol at high and low oxygen partial pressures. FEBS Lett. 238:353-356.

Washam, C. J., G. W. Reinbold, E. R. Vedamuthu, and R. Jorgensen 1974. Changes in milk, whey, and blue cheese as induced by benzoyl peroxide. J. Milk Food Technol. 37:244-249.

Winter, J., M. Ilbert, P. C. F. Graf, D. Ozcelik, and U. Jakob. 2008 Bleach activates a redox-regulated chapter one by oxidative protein unfolding. Cell 135:691-701.

Wright, B. J., S. E. Zevchak, J. M. Wright, and M. A. Drake. 2009 Impact of agglomeration on flavor and flavor stability of whey proteins. J. Food Sci. 74:S17-S29.

Yang, Y., L. Breen, N. A. Burd, A. J. Hector, T. A. ChurchwardVenne, and A. R. Josse. 2012. Resistance exercise enhances myofibrillar protein synthesis with graded intakes of whey protein in older men. Br. J. Nutr. 108:1780-1788.

Zulueta, A., M. J. Esteve, I. Frasquet, and A. Frígola. 2007. Vitamin C, vitamin A, phenolic compounds and total antioxidant capacity of new fruit juice and skim milk mixture beverages marketed in Spain. Food Chem. 103:1365-1374. 